\title{
复 \\ Soil contamination by zoonotic gastrointestinal parasites of mammals in Garanhuns, Pernambuco, Brazil
}

[Geocontaminação por parasitos gastrointestinais zoonóticos de mamíferos em Garanhuns Pernambuco, Brasil]

\section{"Artigo Científico/Scientific Article"}

\section{Naiara Mirelly Marinho da Silva ${ }^{1}$, Marcos Antônio Bezerra Santos ${ }^{1}$, Breno Barros de Santana ${ }^{1}$, Lucia Oliveira de Macedo ${ }^{1}$, Leucio Câmara Alves ${ }^{2}$, Rafael Antonio Nascimento Ramos ${ }^{1}$, Gílcia Aparecida de Carvalho ${ }^{1 *}$}

\author{
${ }^{1}$ Unidade Acadêmica de Garanhuns (UAG), Universidade Federal Rural de Pernambuco, Garanhuns-PE, Brazil. \\ ${ }^{2}$ Departamento de Medicina Veterinária, Universidade Federal Rural de Pernambuco, Recife-PE, Brazil. \\ *Autor para correspondência/Corresponding author: E-mail: gilcia.acarvalho@yahoo.com
}

\begin{abstract}
The increase of canine population in urban areas, which englobes stray or domiciled dogs, has an important epidemiological role in soil contamination of public areas. This increase contributes for the dissemination of infections by parasites via faeces of infected animals. The aim of this study was to detect the presence of immature forms of gastrointestinal parasites of mammals in soil from public roads and squares of the municipality of Garanhuns, state of Pernambuco, Brazil. A total of 211 soil samples were obtained and evaluated through the Faust and Rugai techniques. Out of 211 soil samples, 49.29\% (104/211) scored positive the presence of immature forms of gastrointestinal parasites of mammals, being Ancylostoma sp. (37.91\%) the most frequent. In conclusion, the soil of different parts of the municipality of Garanhuns is contamined by parasites of medical and veterinary concern. Therefore, the implementing of integrated prophylaxis measures is necessary to prevent the soil contamination, reducing the risk of infection for humans.
\end{abstract}

Keywords: Ancylostoma sp.; environment contamination; dogs; zoonosis.

\section{Resumo}

O aumento da população canina em áreas urbanas, tanto de animais errantes quanto domiciliados, tem papel epidemiológico importante na contaminação do solo de áreas públicas. Esse aumento contribui para a disseminação de infecções por parasitos por meio de fezes de animais infectados. O objetivo deste estudo foi verificar a presença de formas imaturas de parasitos gastrintestinais de mamíferos em solo de vias públicas e praças do município de Garanhuns - PE, Brasil. Um total de 211 amostras de solo foram coletadas e avaliadas por meio da utilização das técnicas de Faust e de Rugai. Das 211 amostras de solo, 49,29\% (104/211) foram positivas para formas imaturas de parasitos gastrointestinais de mamíferos, sendo Ancylostoma sp. (37,91\%) o mais frequente. Conclui-se que o solo de diferentes partes do município de Garanhuns está contaminado por parasitos de importância médica e veterinária, fazendo-se necessária a implantação de medidas integradas de profilaxia para minimizar os riscos de infecção para humanos.

Palavras-chave: Ancylostoma sp.; contaminação do ambiente; cães; zoonoses.

\section{Introdução}

Pets, in particular dogs, play an important role in the physical, emotional, and social development of humans (Campos Filho and Barros, 2008). Recently, the increase of dogs' population has favoured the soil contamination of

public areas such as streets, squares, children parks, gardens, beaches and sand boxes in schools (Cassenote et al., 2011; Moura et al., 2013, Traversa et al., 2014, Studzinska et al., 2017). Currently, this is considered an important threat for 
the public, being present in various urban areas of Brazil, where the population of stray dogs occurs. Sometimes, due to the lack of information, dog owners let theirs animals loose in public areas, where they may defecate, contributing for soil contamination by immature forms of gastrointestinal parasites with zoonotic potential (Guimarães et al., 2005).

Immature forms of some parasites, for instance, Ancylostoma caninum and Toxocara canis are frequently detected in soil (Cassetone et al., 2011; Moura et al., 2013), and accidently infect humans. Nonetheless, humans are not the natural host of these parasites which cause Cutaneus Larva Migrans (CLM) and Visceral Larva Migrans (VLM) (Matesco et al., 2006). In general, CLM and VLM do not cause mortality, but may be responsible for cases of allergy, inflammatory reactions, bleeding and blindness (Vasconcelos et al., 2006).

Soil contamination by zoonotic parasites has been reported in public areas in several parts of Brazil (Chen and Mucci, 2012; Sprenger et al., 2014; Prestes et al., 2015). These studies highlight the epidemiological importance of these parasites, and the risk for humans which access contaminated areas such as squares, children parks, gardens, beaches and sand boxes in schools. Based on the lack of information in some areas of Brazil, the aim of this study was to evaluate the presence of immature forms of gastrointestinal parasites of mammals in soil of the municipality of Garanhuns, state of Pernambuco, Northeaster Brazil.

\section{Material and methods Study area}

The study was conducted in the municipality of Garanhuns (latitude 8 ${ }^{\circ} 53^{\prime} 25 " \mathrm{~S}$; longitude $36^{\circ} 29^{\prime} 34^{\prime \prime E}$ ), located in the state of Pernambuco, Northeast region of Brazil. The study area is 900 metres above sea level and has an annual average temperature of $24{ }^{\circ} \mathrm{C}$, average rainfall of $147 \mathrm{~mm}$ (from $25 \mathrm{~mm}$ to $295 \mathrm{~mm}$ ), and air relative humidity of $90 \%$.

\section{Collection and processing of samples}

Sample collections were monthly performed from August 2012 to July 2013 in seven distinct points of the study area (Table 1). Soil samples (approximately $250 \mathrm{~g}$ ) were collected in public squares and roads, from a minimal distance of five metres from the faecal material exposed in the environment. The soils were collected with a gardening shovel with five centimeters deep (Santarém et al., 1998). Samples were stored in plastic bags and maintained at $8{ }^{\circ} \mathrm{C}$ for transport to the laboratory, followed by sample processing. The sampling was defined probabilistically by convenience (Reis, 2003).

The sample processing was performed through the centrifuge-flotation with zinc sulphate technique (Faust et al., 1938) for the observation of eggs, and the Rugai technique (Rugai et al., 1954) for detection of larva. For each sample, one slide was prepared and observed through microscope at magnification of $10 \mathrm{X}$ and $40 \mathrm{X}$.

Table 1. Distribution of samples by point of collection represented by neighbourhoods from Garanhuns - PE, Brazil.

\begin{tabular}{cccc}
\hline Points of Collection & Squares & Public roads & Total \\
\hline Brasília & 0 & 9 & 9 \\
Magano & 9 & 33 & 42 \\
COHAB I & 12 & 11 & 23 \\
COHAB III & 3 & 71 & 74 \\
Indiano & 0 & 27 & 27 \\
Heliópolis & 11 & 1 & 12 \\
Quartel & 12 & 12 & 24 \\
\hline Total & 47 & 164 & 211 \\
\hline
\end{tabular}

\section{Data analysis}

Descriptive statistical analysis was performed. In addition, the Lilliefors test was used to verify the normality of the data. The Chi-square test with Yates correction $\left(\chi^{2}\right)$ was used to compare the occurrence of parasites in the environments ( public roads or squares), as well as the occurrence of parasites species in different ecotypes. A 5\% significance level was considered. The BioEstat software version 5.3 was used for statistical evaluation (Ayres et al., 2000).

\section{Results}

A total of 211 soil samples (47 squares and 164 public roads) were collected in different points of the municipality of Garanhuns. Out of all samples analyzed, in $49.29 \%(104 / 211)$ were 
detected eggs and immature forms of gastrointestinal parasites of mammals. A higher contamination was observed in squares $(68.09 \%$; $32 / 47)$ than in public roads $(43.90 \% ; 72 / 164)\left(\chi^{2}=\right.$ $7.607 ; \mathrm{p}=0.0058)$, in squares simple contamination was observed, whereas in the public roads simple and mixed contamination were (Table 2 and 3). Eggs of Ancylostoma sp. were predominant in squares than in public roads $\left(\chi^{2}=\right.$ 18.698; $\mathrm{p}=0.0000)$. Ancylostoma sp. was the most frequent parasite detected with $37.91 \%(80 / 211)$ of positivity (Table 2).

Table 2. Simple contamination in squares and simple/mixed contamination in public roads by immature forms of gastrointestinal parasites in soil samples collected from the municipality of Garanhuns, PE.

\begin{tabular}{|c|c|c|c|}
\hline \multicolumn{2}{|c|}{ Squares } & \multicolumn{2}{|l|}{ Public roads } \\
\hline \multicolumn{2}{|c|}{ Simple contamination } & \multicolumn{2}{|l|}{ Simple contamination } \\
\hline Parasite & $\%(\mathrm{n} / \mathrm{N})$ & Parasite & $\%(\mathbf{n} / \mathbf{N})$ \\
\hline Ancylostoma sp. & $65.95(31 / 47)$ & Ancylostoma sp. & $29.87(49 / 164)$ \\
\hline Strongyloides sp. & $02.12(01 / 47)$ & Strongyloides sp. & $07.92(13 / 164)$ \\
\hline- & - & Entamoeba coli & $00.60(01 / 164)$ \\
\hline \multicolumn{2}{|c|}{ Mixed contamination } & \multicolumn{2}{|l|}{ Mixed contamination } \\
\hline- & - & Ancylostoma sp. + Strongyloides sp. & $03.04(05 / 164)$ \\
\hline- & - & $\begin{array}{c}\text { Ancylostoma }+ \text { sp. Strongyloides } \mathrm{sp} .+ \\
\text { Toxocara } \mathrm{sp} .\end{array}$ & $02.43(04 / 164)$ \\
\hline
\end{tabular}

Table 3. Frequency of parasites detected in soil samples from Garanhuns PE.

\begin{tabular}{ccc}
\hline Parasites & Frequency & $\mathbf{n}^{\circ}(\mathbf{2 1 1})$ \\
\hline Ancylostoma sp. & 37.91 & $(80 / 211)$ \\
Strongyloides sp. & 06.63 & $(14 / 211)$ \\
Entamoeba coli & 00.47 & $(01 / 211)$ \\
Ancylostoma sp. + Strongyloides sp. & 02.36 & $(05 / 211)$ \\
\hline Ancylostoma sp. + Strongyloides sp. + Toxocara sp. & 01.89 & $(04 / 211)$ \\
\hline Total & 49.28 & $(104 / 211)$ \\
\hline
\end{tabular}

\section{Discussion}

This study assessed the presence of immature forms of gastrointestinal parasites of mammals in soil samples. It is known that the soil contamination by these parasites is a real problem and should be highlighted in developing countries due to their relevance in public health (Papini et al., 2012).

In Brazil, in the municipality of Curitiba, $63.6 \%$ squares (42/66) and $65.2 \%$ of the public roads (45/69) presented geohelminth contamination, presenting a higher frequency $(14.5 \% ; 50 / 345)$ for Ancylostoma spp. (Sprenger et al., 2014). Conversely, in Guarulhos, $74.5 \%$ $(35 / 47)$ of the public areas investigated were contaminated by immature forms of gastrointestinal parasites (e.g., Toxocara spp. eggs) of mammals (Marques et al., 2012). Different from other countries, for example, in Cameroon, Ascaris spp. eggs were most frequent $(2 \% ; 8 / 400)$ (Tchakounté et al., 2018).

Interestingly, the contamination in squares was higher than in public roads, however in this first site only simple contamination has been observed. The presence of a wide range of parasites in public roads may be due to the presence of stray dogs, which has been considered an important trouble in Brazil (Marques et al., 2012). A factor influencing these results is that most squares are located on central areas, which present a lower number of stray dogs most likely due to the socioeconomic status of the residents (Habluetzel et al., 2003).

Among the parasites herein detected, Ancylostoma sp. was the most frequent (37.91\%; 80/211). Similar results have been found in previous studies, with frequencies ranging from $41.07 \%$ to $71.03 \%$ (Scaini et al., 2003; Castro et al., 2005; Capuano and Rocha, 2006). Nonetheless, another study performed in the state of Bahia, Brazil, demonstrated that the frequency of Strongyloides stercoralis was higher than Ancylostoma sp. in sand samples collected from soil beaches. This variation on the contamination profile may be related to the climatic influence as sand sediment may suffer greater influence, associated to wind and rain, than soil from public roads and squares (Silva et al., 2017). The influence of climatic conditions is important 
factors that affect the frequency of geohelminths in each region, justified by the fact that it favours the development and survival of eggs (Tchakounté et al., 2018). From an epidemiological point of view, these findings are relevant, especially considering the zoonotic aspect of those worms (Feldmeier et al., 2006).

This study reinforces the importance of assessment of contamination of soil through mammal faeces in urban areas. This is extremely important, as it allows the knowledge of possible risks for human population, especially children. Therefore, the implementations of preventive measures are needed, as gastrointestinal parasites represent a serious problem in public health.

\section{Conclusion}

The results obtained in this study confirm the presence of zoonotic parasites (Ancylostoma sp.) in public roads and squares in the municipality of Garanhuns, highlighting the importance of the veterinarian in the use of prophylactic antiparasitic drugs and in the indication of control programs for stray animals.

\section{Conflict of interests}

Authors declare no conflict of interests.

\section{References}

Ayres, M.; Ayres Júnior, M.; Ayres, D.L.; Santos, A.S. Bioestat 2.0: Aplicações estatísticas nas áreas das ciências biológicas e médicas. $1^{\mathrm{a}}$ ed. Belém: Sociedade Civil Mamirauá. Brasília: CNPq, 2000. 272p.

Campos-Filho P.C.; Barros L.M. Parasitas zoonóticos em fezes de cães em praça públicas do município de Itabuna, Bahia, Brasil. Revista Brasileira de Parasitologia Veterinária, 17: 206-209, 2008.

Capuano, D.M; Rocha, G.M. Ocorrência de parasitas com potencial zoonótico em fezes de cães coletadas em áreas públicas do município de Ribeirão Preto, SP, Brasil. Revista Brasileira de Epidemiologia, 9: 81-86, 2006. Cassenote, A.J.F.; Neto, J.P.M; Lima-Catelani, A.R.A.; Ferreira, A.W.F. Contaminação do solo por ovos de geo-helmintos com potencial zoonótico na municipalidade de Fernandópolis, estado de São Paulo. Revista da Sociedade Brasileira Medicina Tropical, 44: 371-374, 2011.

Castro, J.M.; Sérgio, V.S.; Monteiro, N.A. Contaminação de canteiros da orla marítima do Município de Praia Grande, São Paulo, por ovos de Ancylostoma e Toxocara em fezes de cães. Revista da Sociedade Brasileira Medicina Tropical, 38: 199-201, 2005.

Chen, A.A.; Mucci, L.N. Frequência de contaminação por helmintos em área de recreação infantil de creches no município de Várzea Paulista, São Paulo, Brasil. Revista de Patologia Tropical, 41: 195-202, 2012.

Faust, E.C.; D'Antoni, J.S.; Odem, V.; Miller, M.J.; Peres, C.; Sawitz, W.; Thomen, L.F.; Tobie, J.; Walker, J.H. A critical study of clinical laboratory technics for the diagnosis of protozoan cysts and helminth eggs in feces. American Journal of Tropical Medicine, 18: 169-83, 1938.

Feldmeier, H.; Jackson, A.; Heukelbach, J.; Calheiros, C.M.L.; Soares, V.L.; Harms G. A study in a community in Brazil in which cutaneous larva migrans is endemic. Clinical Infectious Diseases, 43: 13-18, 2006.

Guimarães, A.M.; Alves, E.G.L.; Rezende, G.F.; Rodrigues, M.C. Ovos de Toxocara sp. e larvas de Ancylostoma sp. em praça pública de Lavras, MG. Revista Saúde Pública 39: 293295, 2005

Habluetzel, A.; Traldi, G.; Ruggieri, S.; Attili, A.R.; Scuppa, P.; Marchetti, R.; Menghini, G.; Esposito, F. An estimation of Toxocara canis prevalence in dogs, environmental egg contamination and risk of human infection in the Marche region of Italy. Veterinary Parasitology, 113: 243-252, 2003.

Marques, J.P.; Guimarães, C.R.; Boas, A.V.; Carnaúba, P.U.; Moraes, J.D. Contamination of public parks and squares from Guarulhos (São Paulo State, Brazil) by Toxocara spp. and Ancylostoma spp. Revista Instituto Medicina Tropical de São Paulo, 54: 267271, 2012.

Matesco, V.C.; Mentz, M.B.; Root, M.B.; Silveira, C.O. Contaminação sazonal por ovos de helmintos na praia de Ipanema, em Porto Alegre, Rio Grande de Sul, Brasil. Revista de Patologia Tropical, 35: 135-141, 2006.

Moura, M.Q.; Jeske, S.; Vieira, J.N.; Correa, T.G.; Berne, M.E.A.; Villela, M.M. Frequency of geohelminths in public squares in Pelotas, RS, Brazil. Revista Brasileira de Parasitologia Veterinária, 22: 175-178, 2013.

Papini, R.; Campisi, E.; Faggi, E.; Pini, G.; Mancianti, F. Prevalence of Toxocara canis eggs in dog faeces from public places of 
Florence, Italy. Helminthologia, 49: 154-158, 2012.

Prestes, L.F.; Jeske, S.; Santos, C.V.; Gallo, C.; Villela, M.M. Contaminação do solo por geohelmintos em áreas públicas de recreação em municípios do sul do Rio Grande do Sul (RS), Brasil. Revista de Patologia Tropical, 44: 155-162, 2015.

Reis, J.C. Estatística aplicada à pesquisa em ciência veterinária. 1a ed. Olinda 2003. $651 \mathrm{p}$.

Rugai, E.; Mattos, T.; Brisola, A.P. Nova técnica para isolar larvas de nematoides das fezes modificação do método de Baermann. Revista Instituto Adolfo Lutz, 14: 5-8, 1954.

Santarém, V.A.; Sartor, I.F.; Bergamo, F.M.M. Contamination by Toxocara spp. eggs in public parks and squares in Botucatu, São Paulo State, Brazil. Revista da Sociedade Brasileira Medicina Tropical, 31: 529-533, 1998.

Scaini, C.J.; Toledo, R.N.; Lovatel, R.; Dionello, M.A.; Gatti, F.A.; Susin, L.; Signorini, V.R.M. Environment contamination by helminth eggs and larvae in dog feces from central area of Cassino Beach, Rio Grande do Sul. Revista da Sociedade Brasileira Medicina Tropical, 36: 617-619, 2003.

Silva, Y.S.; Silva, J.M.S.; Castro, R.C.; Dias, S.O.; Carvalho, S.M.S.; Silva, M.F. Environmental parasitology: Soil analysis for geohelminth larvae contamination in Ilheus, Bahia. Revista de Patologia Tropical, 46: 253-262, 2017.

Sprenger, K.S.; Green, K.T.; Molento, M.B. Geohelminth contamination of public areas and epidemiological risk factors in Curitiba, Brazil. Journal of Veterinary Parasitology, 23: 63-73, 2014.

Studzinska, M.B.; Demkowska-Kutrzepa, M.; Borecka, A.; Meisner, M.; Tomczuk, K.; Roczen-Karczmarz, M.; Klapec, T.; Abbass, Z.; Cholewa, A. Variations in the rate of infestations of dogs with zoonotic nematodes and the contamination of soil in different environments. International Journal of Environmental Research and Public Health, 14: 1003, 2017.

Tchakounté, B.N.; Nkouayep, V.R.; Poné, J.W. Soil Contamination Rate, Prevalence, Intensity of Infection of Geohelminths and Associated Risk Factors among Residents in Bazou (West Cameroon). Ethiopian Journal of Health Sciences, 28: 63-72, 2018.

Traversa, D.; Regalbono, A.F.; Cesare, A.; Torre, F.; Drake, J.; Pietrobelli, M. Environmental contamination by canine geohelminths. Parasites \& Vectors, 7: 67, 2014.

Vasconcelos, M.C.; Barros, J.S.L.; Oliveira, C.S. Parasitas gastrointestinais em cães institucionalizados no Rio de Janeiro, RJ. Revista Saúde Pública, 40: 321-323, 2006. 